\title{
Experimental Investigation of Utilizing Steel Fiber as Concrete Reinforcement in Bridge Decks
}

\author{
Sam Kafaji , Raad Azzawi* \\ Email address: \\ Sam.kafaji@yahoo.com (S. Kafaji), azzawi@uta.edu (R. Azzawi) \\ ${ }^{*}$ Corresponding author
}

Department of Civil Engineering, The University of Texas at Arlington, Texas, Arlington, United States

\section{To cite this article:}

Sam Kafaji, Raad Azzawi. Experimental Investigation of Utilizing Steel Fiber as Concrete Reinforcement in Bridge Decks. Journal of Civil, Construction and Environmental Engineering. Vol. 5, No. 5, 2020, pp. 108-113. doi: 10.11648/j.jccee.20200505.12

Received: August 26, 2020; Accepted: September 17, 2020; Published: September 23, 2020

\begin{abstract}
The study aims to investigate and test the behavior of steel fiber reinforcement concrete material at different dosage of fibers in concrete bridge decks. Concrete is a brittle material therefore the tensile resistance of concrete is low. Steel fiber reinforcement concrete material is a developed material that has been proposed to improve the tensile behavior of the concrete. Steel Fiber Reinforcement is popular material that is being studied to improve the structural behavior of reinforced concrete under different load conditions. Steel fiber-reinforced concrete (SFRC) provides improved tensile performance of concrete. This improved performance can be used in slabs to reduce the volume of conventional steel reinforcement, create longer spans, or reduce slab thickness. The project consisted of twelve concrete slabs has dimensions of (45 inches x 20 inches x 3.5 inches), twelve cylinders has dimensions of (6 inches diameter x 12 inches height) for split tensile test, twelve cylinders has dimensions of (4 inches diameter $\mathrm{x} 8$ inches height) for compression test and twelve beams has dimensions of (6 inches $\times 6$ inches $\times 20$ inches) for modulus of rupture test. each three concrete slabs and specimens has same dosage of steel fiber reinforcement starting with $0.0 \%, 0.5 \%, 1.0 \%$ and $1.5 \%$ in order to investigate and exam the concrete behavior. The experiment revealed that the increase in the dosage of steel fiber fraction increases the compressive strength of the concrete in addition to that the breakout strength of concrete in tension increased. It is also found that the steel fiber improves the ductility of concrete and that is clear in the "Load- Deflection response figures" the area under the curves increases compare with normal concrete while the crack width became thinner with the increasing of the steel fiber dosage and preventing the sudden collapse as in normal concrete. Taking those results into consideration this can make a reduction in structural weight and improve the safety and speed up the construction and cost saving in the short term and the long term.
\end{abstract}

Keywords: Steel Fiber, Concrete Mix, Concrete Breakout, Experimental Study, Flexural Strength

\section{Introduction}

As known the plain concrete have low strength-Strain capacity, however, by adding Steel Fiber to the mix these properties could be improved [3], it may allow the thickness of the layer to be reduced. Adding Steel fiber to the concrete mixture as reinforcement is to control and influence the tensile cracking of concrete [2].

Since the Steel Fiber randomly distributed in the Concrete mixture this improving the concrete properties such as ductility, flexural strength and toughness, Steel Fiber Reinforcement Concrete has been widely used in pavements, hydraulic structures, airport, industrial floors, parking lots and bridge decks. Modulus of Elasticity of steel fibers is as high as (30 ksi) which is providing high tensile strength with minimal deformation. The researches have stated that SFRC improve the impact resistance of concrete making it a proper material for structures to impact loads. In general, the SFRC is most beneficial material as of engineering and economical point of view to be considered for structural slabs subjected to high relatively loads. In this experiment. The goal of this study is explained below. 


\section{Experiment Program}

Four different types of mixtures were designed according to the test to be performed, the compressive strength of plain concrete is designed for a target of (4000 psi). Four different type of SFRC ratio are used, each mixture of SFRC has different dosage of steel fibers. Table 1 below shows different concrete mixture for this study. Portland cement type I, sand for fine aggregate, and gravel were used. The specimen were taken for each concrete mixture, In total, 12-cylinder specimens of 4-inch diameter and 8-inch height for compressive strength (3 cylinders for each type of concrete mixture), 12-cylinder specimens of 6-inch diameter and 12inch height for tensile strength (3 cylinders for each type of concrete mixture), 12- beam specimens of $6 \times 6 \times 20$ inch for Flexural test ( 3 beams for each type of concrete mixture), and 12 -slabs $45 \times 20 \times 3.5$ inch ( 3 slabs for each type of concrete mixture), were produced and tested after 28 days of curing [6].

Table 1. Mix proportions of the concrete mixtures for 1 Cubic Yard.

\begin{tabular}{|c|c|c|c|c|c|c|c|}
\hline Mixture name & Cement (Ibs) & Water (lbs) & Fine Aggregate (lbs) & Coarse Aggregate (lbs) & $\mathbf{w} / \mathbf{c}$ & Fiber* \% & Fiber (lb) \\
\hline $\mathrm{RC} 0$ & 680 & 306 & 1752 & 1263 & 0.45 & 0.0 & 0 \\
\hline SFRC 0.5 & 677 & 304 & 1743 & 1257 & 0.45 & 0.5 & 20.0 \\
\hline SFRC 1.0 & 674 & 302 & 1734 & 1251 & 0.45 & 1.0 & 40.0 \\
\hline SFRC 1.5 & 671 & 300 & 1725 & 1245 & 0.45 & 1.5 & 60.0 \\
\hline
\end{tabular}

* By wt. of concrete

\section{Concrete Tests}

\subsection{Slump Test}

With the same circumstances (water to cement ratio) for all four type of mixes the slump value was changing [7]. Increase the Steel Fiber ratio in the mix decreases the Slump value and that decreases the workability of the concrete. In general, the workability of SFRC was less than plain concrete due to the additional surface area of the Steel fiber that added to the mix is a factor to consider. Table 2. slump test values.

Table 2. Slump test results.

\begin{tabular}{llll}
\hline Mixture name & \% Fiber & w/c & Slump Measurement (in) \\
\hline PC $0 \%$ & 0.0 & 0.45 & 8 \\
SFRC $0.5 \%$ & 0.5 & 0.45 & 5.5 \\
SFRC $1.0 \%$ & 1.0 & 0.45 & 5 \\
SFRC $1.5 \%$ & 1.5 & 0.45 & 4 \\
\hline
\end{tabular}

\subsection{Compressive strength of cylinder}

Each mix of concrete, numbers of Cylinders were casted and tested under a uniaxial compression load, a 500-kip compression machine is used to perform the ASTM C39 test with load rate of $400 \mathrm{lb} / \mathrm{sec}$ [8]. Table 3 summarized the results. The compressive strength of the concrete was measured using Equation (1), see Figure 1. The increases in compressive strength from $0 \%$ to $0.5 \%, 0.5 \%$ to $1 \%$ and $1 \%$ to $1.5 \%$ was $17 \%, 5 \%$ and $4 \%$ respectively.

$$
f c=\frac{P}{\pi r^{2}}
$$

Table 3. Average Compressive Strength Test Results.

\begin{tabular}{lllll}
\hline $\begin{array}{l}\text { Concrete } \\
\text { Mix }\end{array}$ & $\begin{array}{l}\text { Specimen } \\
\text { No. }\end{array}$ & $\begin{array}{l}\text { Max Load } \\
\text { (lbs) }\end{array}$ & $\begin{array}{l}\text { Stress } \\
\text { (psi) }\end{array}$ & $\begin{array}{l}\text { Average } \\
\text { Stress (psi) }\end{array}$ \\
\hline \multirow{2}{*}{ PC } & 1 & 49120 & 3909 & \\
$0 \%$ & 2 & 36270 & 2886 & 4017 \\
& 3 & 51830 & 4125 & \\
\hline
\end{tabular}

\begin{tabular}{lllll}
\hline $\begin{array}{l}\text { Concrete } \\
\text { Mix }\end{array}$ & $\begin{array}{l}\text { Specimen } \\
\text { No. }\end{array}$ & $\begin{array}{l}\text { Max Load } \\
\text { (lbs) }\end{array}$ & $\begin{array}{l}\text { Stress } \\
\text { (psi) }\end{array}$ & $\begin{array}{l}\text { Average } \\
\text { Stress (psi) }\end{array}$ \\
\hline & 1 & 71130 & 5660 & \\
SFRC 0.5\% & 2 & 53430 & 4252 & 4716 \\
& 3 & 53220 & 4235 & \\
& 1 & 61230 & 4873 & \\
SFRC 1\% & 2 & 61730 & 4912 & 4961 \\
& 3 & 64070 & 5099 & \\
& 1 & 48080 & 4818 & \\
SFRC 1.5\% & 2 & 69550 & 5535 & 5134 \\
& 3 & 63430 & 5048 & \\
\hline
\end{tabular}

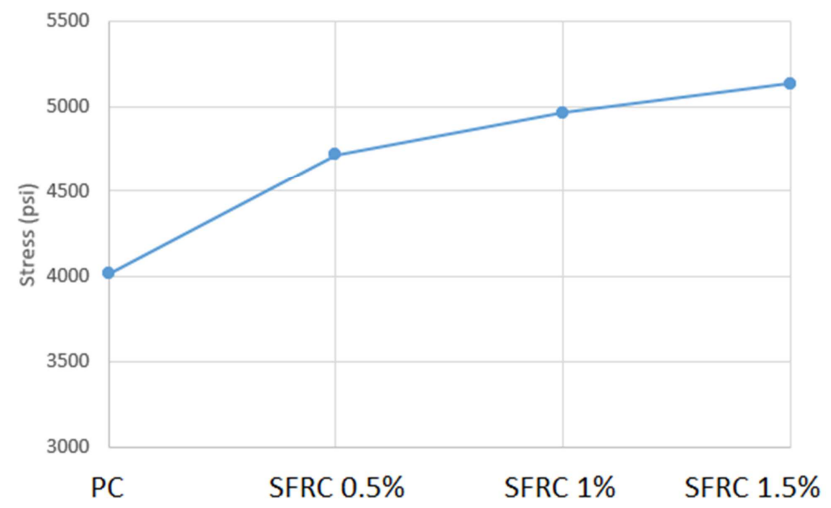

Figure 1. Average Cylinder Compression Test Results.

\subsection{Split Tensile Test}

12 cylinders accompanying their respective large-scale slabs are used for performing a split-cylinder test according to ASTM C496 using the 500-kip compression machine with loading rate of 100 to $200 \mathrm{lb} / \mathrm{in} 2$ per minute until the specimen develops a tension crack along its diameter [9], all the tensile results are in Table 4. The tensile strength of the concrete was measured using Equation (2). See Figure 2. The increases in tensile strength from $0 \%$ to $0.5 \%, 0.5 \%$ to $1 \%$ and $1 \%$ to $1.5 \%$ was $21 \%, 10 \%$ and $16 \%$ respectively.

$$
f t=\frac{2 P}{\pi L D}
$$


Table 4. Average Tensile Test Results.

\begin{tabular}{lllll}
\hline $\begin{array}{l}\text { Concrete } \\
\text { Mix }\end{array}$ & $\begin{array}{l}\text { Specimen } \\
\text { No. }\end{array}$ & $\begin{array}{l}\text { Max Load } \\
\text { (lbs) }\end{array}$ & $\begin{array}{l}\text { Stress } \\
\text { (psi) }\end{array}$ & $\begin{array}{l}\text { Average } \\
\text { Stress (psi) }\end{array}$ \\
\hline \multirow{2}{*}{ PC 0\% } & 1 & 48860 & 432 & \\
& 2 & 48340 & 427 & 415 \\
& 3 & 43600 & 386 & \\
SFRC 0.5\% & 1 & 55560 & 491 & \\
& 2 & 56780 & 502 & 504 \\
SFRC 1\% & 2 & 58790 & 520 & \\
& 3 & 60550 & 535 & \\
& 3 & 64320 & 569 & 554 \\
SFRC 1.5\% & 2 & 63210 & 559 & \\
& 3 & 69870 & 618 & \\
\end{tabular}

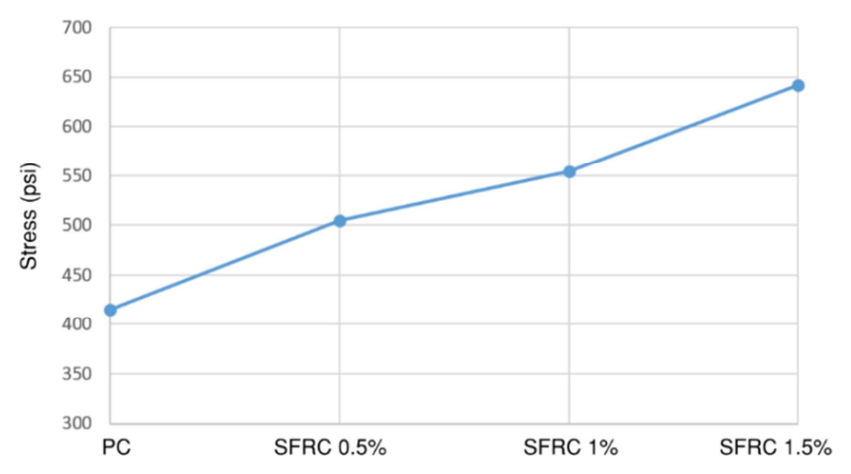

Figure 2. Average Cylinder Tensile Test Results.

\subsection{Flexural Beam Test}

It is indirect method of testing and evaluating the tensile strength of concrete. Each mix type, numbers of beams were taken to be tested under compression load. The mold had dimensions of $6 \times 6 \times 20$-inch. The test is four points bending test. the test was done according to ASTM C78, the clear span was set to 18 -inch and the upper bearer distance was set to 6-inch [10]. The results of the Flexure test for all concrete types are summarized in Table 5. The flexure strength of the concrete was measured using Equation 3, see Figure 3. With the addition of steel fibers of $0.5 \%, 1.0 \%$ and $1.5 \%$ the flexural strength of concrete increased by $2.6 \%, 16 \%$, and $7.8 \%$ respectively.

$$
f r=\frac{P L^{\prime}}{B D^{\prime 2}}
$$

Table 5. Flexure Test Results.

\begin{tabular}{lllll}
\hline $\begin{array}{l}\text { Concrete } \\
\text { Mix }\end{array}$ & $\begin{array}{l}\text { Specimen } \\
\text { No. }\end{array}$ & $\begin{array}{l}\text { Max Load } \\
(\mathbf{l b s})\end{array}$ & $\begin{array}{l}\text { Stress } \\
\text { (psi) }\end{array}$ & $\begin{array}{l}\text { Average } \\
\text { Stress (psi) }\end{array}$ \\
\hline \multirow{3}{*}{ PC 0\% } & 1 & 6482 & 540 & \\
& 2 & 6767 & 564 & 561 \\
SFRC 0.5\% & 3 & 6948 & 579 & \\
& 1 & 6744 & 562 & \\
& 3 & 7130 & 594 & 576 \\
SFRC 1\% & 1 & 6843 & 570 & \\
& 2 & 9265 & 772 & \\
& 3 & 7671 & 639 & 668 \\
SFRC 1.5\% & 2 & 7122 & 594 & \\
& 3 & 7806 & 651 & \\
\hline
\end{tabular}

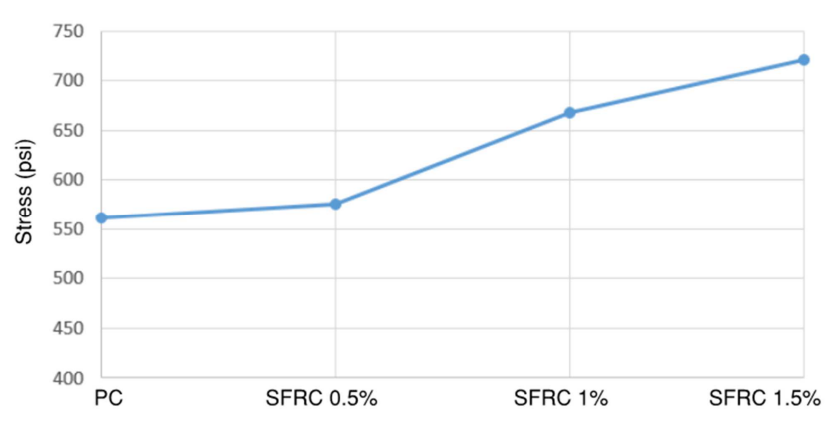

Figure 3. Average Beams Flexure Test Results.

\section{5. “3.5-inch” Thick Slabs Test}

12 Flexural slabs were tested after 28 days of curing, 3 slabs for each concrete mixture as shown in Figure 4-a, b, c and d. A simply supported setup is used for testing of the 12 Concrete Slabs using the 400-kip compression machine [11]. The machine has two cross-heads, one on the top and one on the bottom. The top cross-head stays fixed in place after initial adjustments are made to accommodate the supports, the beam, the load plates and the load cell. The lower cross-head moves upward in a steady manner and the machines load cell monitors the loading rate. 6 feet long wide-flange steel girders are aligned on the lower plate. The roller and pin support on the two ends are placed on the steel girder. A rollers support permitting lateral translation is used on the left end of the beam and pin support with no allowable lateral translation is setup on the right end of the beam as shown in Figure 5. Aligning and centering the girders the supports and specimen under the loading plate is fundamental to obtaining accurate results. The objective here is to make sure that the point load is applied exactly at the midspan of the slab and that the supports are at their designated location in accordance with the slab design criteria of the study. Moreover, the load cell is placed on top of 3 plates that are placed on top of the slab. Once the setup is ready for testing, a monotonic load $2.2 \mathrm{kip} /$ minute constant point load is applied. Simultaneously, the load cell records the instantaneous load applied and the Micro-Measurements records the mid-span deflection of the beams. The Micro-Measurements tool placed on the top of steel girder under the concrete slab and vertically intersects a thin aluminum plate attached under the concrete slab to take deflection measurements, as shown in Figure 6. It is noteworthy to mention that all the measuring devices used for testing were calibrated by their respective manufacturers before any test was carried out. All the recordings were transmitted to a network of data acquisition scanners. The scanner network comprised of 3 Micro-Measurements VPG scanners connected to each other using relay cables, this provided 60 available channels. Data is obtained at a 0.02 second time intervals.

Furthermore, each load cell and Micro-Measurement tool are connected to the scanner network using wiring adaptors acquired from strain gauge manufacturing firm. The main scanner within the network is the connected to a windows based Strain Smart equipped computer using PC5101B PCMCIA interface adapter. As a result, the assembly produces accurate and reliable test data which lays a concrete 
foundation for performing an accurate stress analysis study.
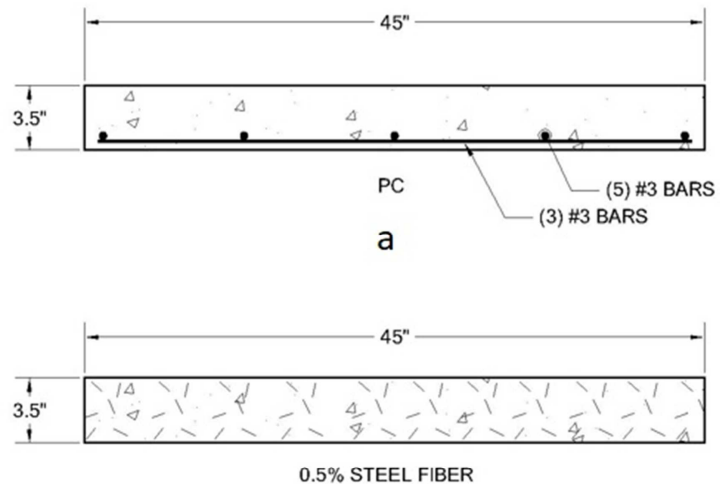

b

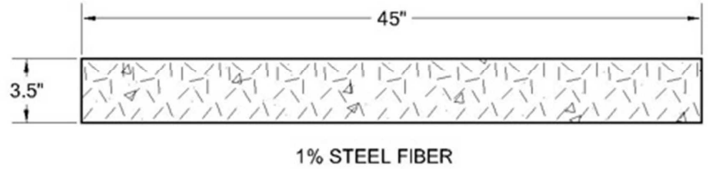

C

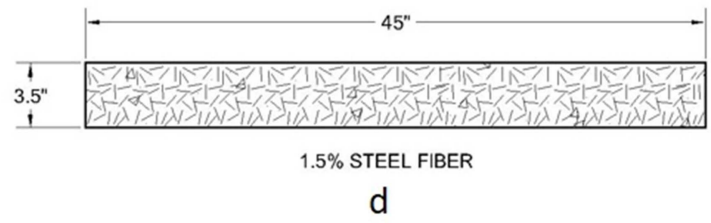

Figure 4. Slabs Specimens.

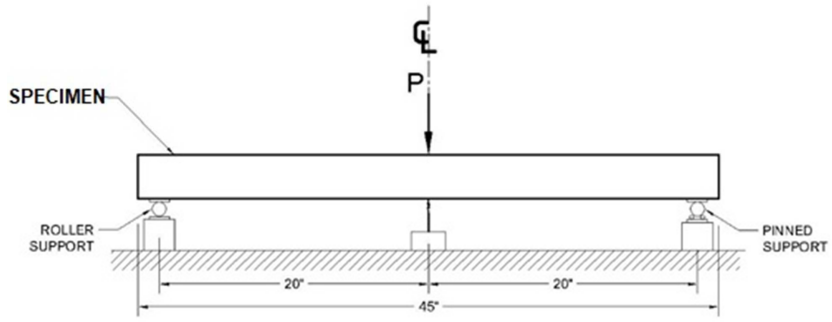

Figure 5. Simply Supported Slab setup.

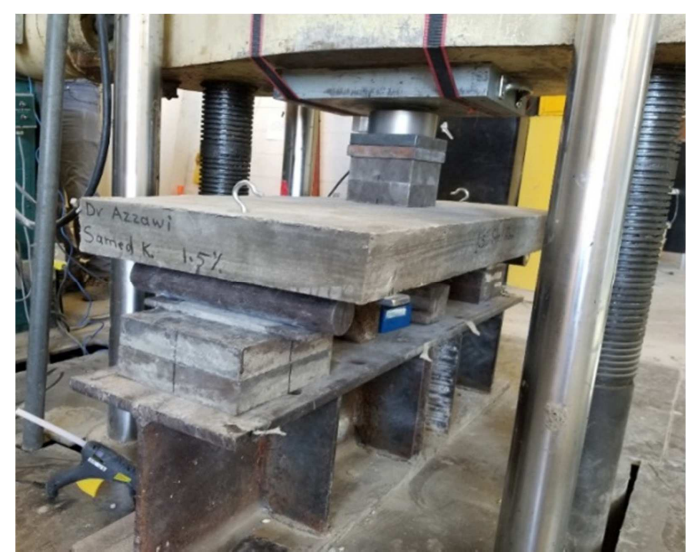

Figure 6. Testing setup

\section{Analysis of Test Results}

\subsection{Reinforcement Concrete Slabs with No Steel Fibers (RC 0\%)}

The average maximum load of the 3 concrete slabs with $0 \%$ steel fiber and minimum steel reinforcement of \# 3 bars at 8 " center to center as shown in Figure 4 (a), was 9259 lbs before it fails, the first crack developed when the load was around $4500 \mathrm{lbs}$ then the reinforcement started carrying the load up to $9259 \mathrm{lbs}$ with very high deflection which is 1.053 in see Table 6 , and the cracks width was around 0.15 inch. Figure 7 shows the load-deflection behavior.

Table 6. Average Maximum Load-Deflection Test Results of Slabs.

\begin{tabular}{llllll}
\hline $\begin{array}{l}\text { Concrete } \\
\text { Mix }\end{array}$ & $\begin{array}{l}\text { Specimen } \\
\text { No. }\end{array}$ & $\begin{array}{l}\text { Max } \\
\text { Load } \\
\text { (lbs) }\end{array}$ & $\begin{array}{l}\text { Max } \\
\text { Deflection } \\
\text { (in) }\end{array}$ & $\begin{array}{l}\text { Average } \\
\text { Load } \\
\text { (lbs) }\end{array}$ & $\begin{array}{l}\text { Average } \\
\text { Deflection } \\
\text { (in) }\end{array}$ \\
\hline $\begin{array}{l}\text { RC } \\
(0 \%\end{array}$ & 1 & 9169 & 0.94 & & \\
Fiber) & 2 & 9894 & 1.26 & 9259 & 1.053 \\
& 3 & 8715 & 0.96 & & \\
SFRC & 1 & 4080 & 0.025 & & \\
$(0.5 \%)$ & 2 & 4283 & 0.026 & 3958 & 0.023 \\
& 3 & 3510 & 0.019 & & \\
SFRC & 1 & 4586 & 0.034 & & \\
$(1 \%)$ & 2 & 4550 & 0.037 & 4564 & 0.031 \\
& 3 & 4555 & 0.023 & & \\
\hline $\begin{array}{l}\text { SFRC } \\
(1.5 \%)\end{array}$ & 1 & 5800 & 0.037 & & \\
\hline
\end{tabular}

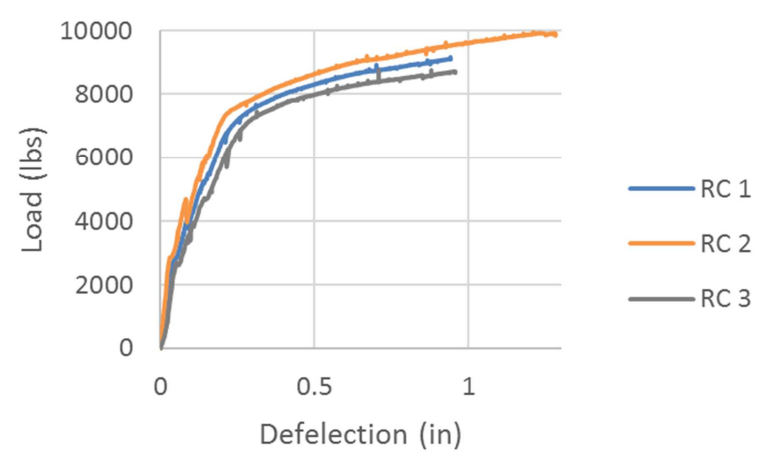

Figure 7. Load-Deflection response for RC 0\% Slab \#1, 2 and 3.

\subsection{Concrete Slabs with 0.5\% Steel Fiber SFRC (0.5\%)}

The average maximum load of the 3 concrete slabs with $0.5 \%$ steel fiber SFRC (0.5\%) as shown in Figure 4 (b), was $3958 \mathrm{lbs}$ before it fails, see Table 6, the cracks developed at the maximum load and the load started decreasing with increasing of the deflection to reach the maximum average deflection of 0.023 inch as shown in Figure 8, the average maximum deflection was 0.023 inch. 


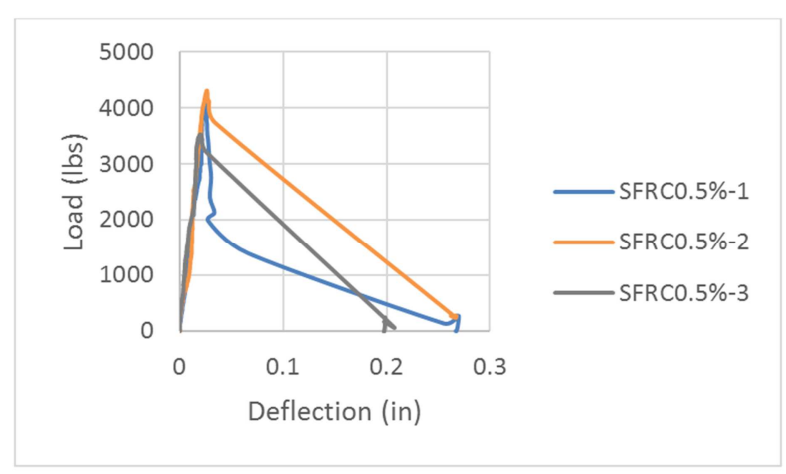

Figure 8. Load-Deflection response for SFRC (0.5\%) Slab \#1, 2 \& 3.

\subsection{Concrete Slabs with 1\% Steel Fiber SFRC (1\%)}

The average maximum load of the 3 concrete slabs with $1 \%$ steel fiber SFRC (1\%) as shown in Figure 4 (c), was $4564 \mathrm{lbs}$ before it fails see Table 6 , the cracks developed at the maximum load and the load started decreasing with increasing in deflection as shown in Figure 9, the average cracks width was around 0.1 inch.

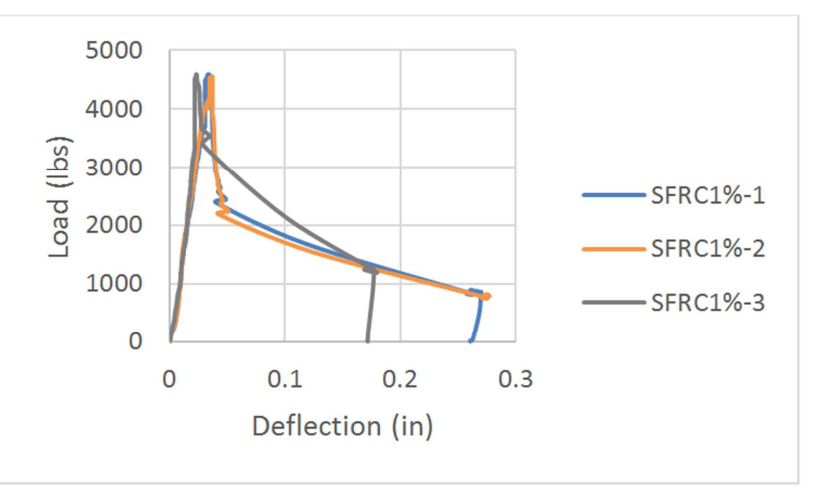

Figure 9. Load-Deflection response for SFRC (1\%) Slab \#1, 2 \& 3.

\subsection{Concrete Slabs with 1.5\% Steel Fiber SFRC (1.5\%)}

The average maximum load of the 3 concrete slabs with $1.5 \%$ steel fiber SFRC (1.5\%) as shown in Figure $4(\mathrm{~d})$, was $5606 \mathrm{lbs}$ before it fails see Table 6 , the cracks developed at the maximum load and the load started decreasing with increasing in deflection as shown in Figure 10, the average cracks width was around 0.08 inch.

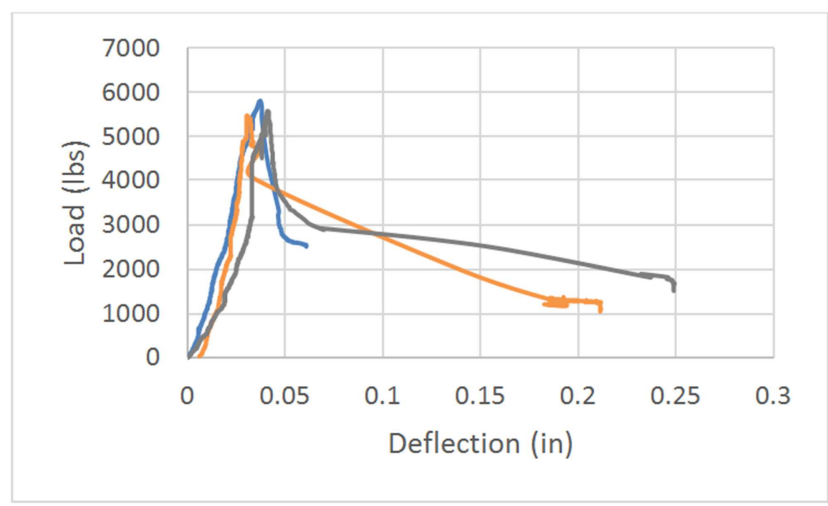

Figure 10. Load-Deflection response for SFRC (1.5\%) Slab \#1, 2 \& 3.

\section{Summery and Conclusions}

\subsection{Summary}

In summary, the flexure strength performance and failure mechanism of 12 concrete slabs with/without Steel Fiber are studied and discussed in this research study. $45 \mathrm{x} 20 \mathrm{x}$ 3.5 inch slabs with various fiber dosage were produced and tested at Civil Engineering Laboratory Building (CELB) at the University of Texas at Arlington. The Average concentrated load results clearly showed that it is increasing proportionally with the increase of the steel fiber. With the addition of steel fibers in fraction of $0.5 \%$ and $1.0 \%$ the maximum load applied on concrete slab increased by $15.3 \%$ while the increase in maximum load with the addition of steel fiber in fraction of $1 \%$ to $1.5 \%$ is $22.8 \%$, fibers had the highest effect on the maximum load while $1.5 \%$ had almost higher effect on the strength. Also the concrete slabs behaves as more ductile materials with the higher dose of steel fiber and this is clearly shown that the deflection before they fail with $0.5 \%$ of steel fiber (SFRC0.5\%) was $0.023 \mathrm{inch}$ and this goes up to 0.0313 inch with $1 \%$ of steel fiber (SFRC1\%) and then goes to 0.036 inch with $1.5 \%$ of steel fiber (SFRC1.5\%).

\subsection{Conclusion}

In general, the performance of the concrete slabs was increasing with the increase of steel fiber. The increase in compressive strength was relatively low, the high dosage of steel fiber may increase the air content and reduce the compressive strength [2]. The tensile strength of the concrete slabs increased proportionally with the increase of steel fiber. The flexure strength of the concrete slabs increased proportionally with the increase of steel fiber. The behavior of the concrete slabs with steel reinforcement was better than the concrete slabs with steel fiber because the steel reinforcement was carrying the load right after the cracks occurred. The area under the Load-Deflection curve increased with the increased of the steel fiber so its mean the concrete slabs with steel fibers were gaining strength with the increase of the steel fiber and this is clearly shown on the Load-Deflection figures. With the increase of dosage of steel fiber, the width of the crack of the concrete slabs decreased and turned from sudden cracks to gradually cracks so that's mean the concrete behaved as a ductile material with a high dosage of steel fiber. The deflection right before the failure happened of the concrete slabs increased with the increase of the steel fiber dosage. The total cost of steel fiber reinforced concrete is less than the cost of steel bars reinforced concrete. The construction time by using the steel fiber reinforced concrete is much less than the steel bars reinforced concrete and this will speed up the construction time of the projects and fast return of project incensement [1]. The steel fiber has more corrosion resistant options over the conventional reinforcing bars as corrosion of reinforcing steel in the most common path to failure of the bridge deck. 


\section{Notation}

The following Symbols are used in this paper:

$\mathrm{B}=$ width of beam

$\mathrm{D}=$ diameter of cylinder

$\mathrm{D}^{\prime}=$ depth of beam

$\mathrm{d}=$ diameter of anchor head

$\mathrm{d}$ '=breakout diameter

$\mathrm{Df}=$ fiber diameter

$\mathrm{fr}=$ modulus of rupture

$\mathrm{ft}=$ tensile strength

$\mathrm{f}^{\prime} \mathrm{c}=$ concrete compressive strength

hef=effective embedment depth

$\mathrm{L}=$ length of cylinder

$\mathrm{L}^{\prime}=$ span of beam

$\mathrm{Lf}=$ length of fiber

$\mathrm{Nb}=$ ultimate tensile breakout load

$\mathrm{P}=$ ultimate load

$\mathrm{r}=$ radius of cylinder

\section{References}

[1] Joshua A. Mcmahon and Anna C. Birely Experimental Performance of Steel Fiber Reinforced Concrete Bridge Deck. 2018.

[2] Ahmad Bazgir. The behaviour of steel fibre reinforced concrete material and its effect on impact resistance of slabs. Semantic Scholar, 2016.

[3] Karthik Kondajji, experimental investigation of concrete breakout strength of anchor in tension within fiber reinforced concrete, 2019.
[4] Nancy Varughese, Flexural Behavior of Preflex SFRCEncased Steel Joist Composite Beams. 2020.

[5] Yanxia Ye, Experimental Study of High-Strength Steel Fiber Lightweight Aggregate Concrete on Mechanical Properties and Toughness Index, 2020.

[6] ASTM C192, Standard Practice for Making and Curing Concrete Test Specimens.

[7] ASTM C143/C143M, Test Method for Slump.

[8] ASTM C39, Test Method for Compressive Strength of Cylindrical Concrete Specimens.

[9] ASTM C496, Test Method for Splitting Tensile Strength of Cylindrical Concrete Specimens.

[10] ASTM C78 (Test Method for Flexural Strength of Concrete).

[11] ASTM E290-14 Standard Test Methods for Bend Testing of Material for Ductility.

[12] ACI Committee 318 Building Code Requirements for Structural Concrete, ACI 318-19 and Commentary ACI 318R19 American Concrete Institute, Farmington Hills, MI, 2019.

[13] X. Yan, L. M. Liu, J. P. Zhang, Y. H. Li, and H. Wang, Experimental study on basic mechanical properties of steel fiber-reinforced siliceous wet shotcrete, 2018.

[14] F. Y. Li, C. Y. Cao, Y. X. Cui, and P. F. Wu, Experimental study of the basic mechanical properties of directionally distributed steel fiber-reinforced concrete, 2018.

[15] X. Z. Wang, J. He, A. S. Mosallam, C. X. Li, and H. H. Xin, The effects of fiber length and volume on material properties and crack resistance of basalt fiber reinforced concrete, 2019. 